\title{
Study on Application of "Output-oriented Teaching Method" in College English Teaching
}

\author{
Yanling Sun \\ School of Foreign Languages, Shangqiu Normal University, Shangqiu, Henan, 476000, China
}

Keywords: output-oriented teaching method; College English teaching; application; strategy

\begin{abstract}
English is playing an increasingly important role in current employment environment. Excellent English ability is also a basic condition for student employment and development. Therefore, it is necessary to pay enough attention to English teaching and keep improving students' overall quality of English in the practice of college English teaching. However, in view of the current college English teaching practice, there still exist some problems. The output-oriented teaching method is an effective form of English teaching, which can effectively improve students' English application ability. This paper has specifically elaborated countermeasures for the effective application of output-oriented teaching method in college English teaching.
\end{abstract}

\section{Introduction}

English is a key subject in the period of college education. Good English ability can directly reflect the overall quality of students. In view of the current situation of college English teaching, under the influence of traditional teaching methods, there are still certain problems which are also obstacles affecting students of the improvement of English ability. Therefore, how to solve these problems is currently an issue that college English teachers consider seriously. The output-oriented teaching method is a relatively new form of teaching which plays an active role in stimulating students' interest in learning during the application in the teaching process.

\section{The Positive Significance of Output-oriented Teaching Method in College English Teaching}

\subsection{It can help students to give play to their subjective initiative and improve teaching quality}

Teachers are only the guides and participants of student learning $i$ the process of classroom teaching. Students are the main body of learning. To maximize the actual function of teaching, and guide students to actively learn and explore new knowledge, teachers should actively guide students and give full play to students' subjectivity. But as per the traditional teaching pattern, as the teacher spend most of time explaining in the classroom, students generally lack learning confidence with high degree of dependence on teachers, and do not have independent thinking time during the learning in a relatively passive position. Even with their own ideas, they do not dare to speak out it directly. In the long run, it will seriously affect teaching efficiency ${ }^{[1]}$. The application of output-oriented teaching method in college English teaching can change this kind of inefficient teaching mode, effectively excavate students' own potential, motivate students' desire to explore knowledge so that students can gradually establish a good awareness of subjectivity in the process of learning and give full play to their subjective initiative. We must respect students $\square$ individual development and help them to eliminate fear mentality to learn new knowledge during learning, establish self-confidence, and continuously improve overall quality.

\subsection{It conforms to the overall requirements of the education development trend}

Under the current educational development trend, in-depth implementation of curriculum reform has brought new opportunities for the development of traditional teaching patterns, and popularized the concept of quality education among people, which is the mainstream trend of the current 
educational development forms as well as the basic requirement. For better helping students to understand and master relevant knowledge, promoting student learning and development, it is

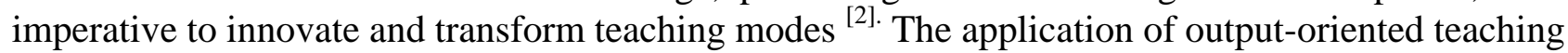
method in college English teaching highlighting students' learning autonomy can help students to break through the bottleneck of ability enhancement while learning basic knowledge, and gradually establish their own independent thinking capability, thus in accordance with the overall requirements of current education development.

\section{Main Problems in Applying Output-oriented Teaching Method in College English Teaching}

\subsection{The lack of scientific and reasonable planning in teaching content}

Whether teachers' teaching contents are scientific and reasonable is very critical for students in the process of learning, which will also directly concern the degree of students' acceptance and understanding. For the same knowledge content, if the teacher provides scientific and rational planning before the lecture, and carry out teaching activities in strict accordance with the established plan during teaching, students will receive and understand knowledge very fast. However, on the contrary, students $\square$ learning effect will be affected. In current college English teaching practice, the application of the output-oriented teaching method is not very scientific. Some teachers which purpose overall teaching quality and teaching effects blindly impark theoretical knowledge, impark theoretical knowledge blindly and formulate teaching plans simply following their own willingness. They believe only improving the teaching standards can improve students $\square$ overall quality and ignore students' learning and growth characteristics in the teaching practice, which causes inconsistencies between students $\square$ learning and actual intellectual development. In this case, the expected function to improve teaching quality cannot be achieved, instead, it may have a greater negative impact on students' future learning.

\subsection{The formalized application of output-oriented teaching method, lacking substantive significance}

It has been a period of time to carry out the new round of curriculum reform and achieved some initial results. With the progress of curriculum reform, some more innovative teaching methods have gradually emerged, some of which are very effective. The application of the teaching process has changed the traditional teaching patterns and teaching concepts, and greatly improved the overall quality of teaching. However, there are still certain problems in this process. The output-oriented teaching method is very representative one among them ${ }^{[3]}$. Under the influence of some teachers' inherent teaching concepts, the acceptance degree of output-oriented teaching methods is relatively low with a certain degree of deviation in understanding. Therefore, in the process of practical application, these teachers are subject to the trend of curriculum reform and pursue the formal innovation of teaching, which is just the innovation of formal application. Some teachers even ignore the original purpose of the teaching in the pursuit of teaching form. In view of this from the surface, the teachers have applied the output-oriented teaching method but failed to give play to the expected function of the output-oriented teaching method. They sometimes waste a lot of class time because of pursuing the teaching style, which affects the overall teaching quality. So it gets more kicks than halfpence.

\subsection{Lack of effective communication with students in the teaching process}

The classroom teaching process is also a process of communication between students and teachers. Through effective communication, teachers can understand and master the students' learning situation, and they can skip the knowledge point that students have acquired. If the students have common problems, the teacher will give specific instruction and targeted explanation, which not only saves a lot of valuable classroom time, but also improves the overall efficiency of classroom teaching. However, all of these are based on effective communication between teachers and students. If $t$ lack 
of communication between the teacher and the student, or not smooth communication, teachers cannot timely graspt the actual learning situation of the student, which is reflected into lacking targeted teaching. Students will follow the teacher's thinking during the classroom learning process without independent thinking. This is a common problem in the current process of college English teaching when applying output-oriented teaching methods. Under such circumstances, the adoption of any teaching measures is blind and untargeted.

\section{The Effective Application Countermeasure for Output-oriented Teaching Method in College English Teaching}

\subsection{Strengthen teachers' understanding of output-oriented teaching methods and effectively improve the quality of English teaching}

During students' learning process, teachers play a very crucial role. We can say that teachers' overall quality has an important influence on students' learning situation and directly concerns students' mastery and understanding of knowledge. Therefore, in the practice of college English teaching, to effectively improve teaching quality and promote the better application of the output-oriented teaching method, more efforts should be paid to improve teachers $\square$ teaching quality. Particularly, under the background of the deep implementation of teaching reform, teaching methods are constantly emerging. So only after teachers have high professional qualities and profoundly understood the substantive requirements of the output-oriented teaching method can they make appropriate choices in the teaching process, maximize the practical role of the output-oriented teaching method, and improve English teaching effectiveness ${ }^{[4]}$. In this process, schools can actively organize teachers to carry out teaching exchange activities, and learn from each other's problems and experiences in the teaching process, so as to deepen teachers' understanding of classroom teaching and continuously learn excellent teaching methods, thus laying good foundation for better application of output-oriented teaching method in college English teaching.

\subsection{Establish clear teaching objectives and improve the pertinence of output-oriented teaching method}

In the current college English teaching process, one of the main problems that affect teaching quality improvement and the application of output-oriented teaching methods is the unclear teaching objectives. To fundamentally solve this problem, teachers should firstly establish clear teaching goals before teaching. Specifically speaking, the teachers should deeply understand the students' English learning situation and their mastery of the level of knowledge under the guidance of teaching program in the precondition of meeting the college English teaching standard, and then combine the curriculum standards to formulate scientific and reasonable teaching goals, abandon the incorrect teaching methods of randomly arranging classes according to their will. In this way, they can help students to establish a complete knowledge system of mathematics through scientific teaching design, consider to review what they have learned while explaining new knowledge, and promote better application of output-oriented teaching method. By doing so, students can learn new things in the process of classroom teaching, form a benign teaching cycle, and gradually improve students $\square$ overall quality.

\subsection{Strengthen teacher-student communication and timely solve problems in the teaching process}

Communication is the major way to understand students, as well as the basic condition for teachers to improve the teaching mode and improve the quality of teaching. Therefore, in the process of college English teaching, teachers should actively communicate with students to promote the better application of output-oriented teaching methods, keep abreast of the students' learning situation and problems, and then adjust the application of the output-oriented teaching method ${ }^{[5]}$. For the students' problems in the learning process, teachers should not blindly criticize them, instead, they should treat 
students differently according to specific circumstances. Individual issues should be individually explained. Common problems should be targeted for reinforcement, which can help students to remove the obstacles in the learning process and improve the students $\square$ comprehensive quality. When students meet problems which are hard to solve, they should provide appropriate psychological counseling and help students build their confidence in learning, eliminate fears mentality of learning new knowledge, and help students face their own problems, and avoid fearful emotions. The teacher can adjust the teaching plan in time according to students $\square$ actual learning situation to improve the pertinence and effectiveness of college English teaching.

\subsection{Focus on maintaining the systematicness of college English knowledge}

Due to highly systematic knowledge in teaching practice, it is necessary to follow systematic principles in the learning process and avoid to separate knowledge integrity and create obstacles in understanding. Under the background of the current era of network development with fragmented information knowledge flooding the entire network, some teachers under this influence currently implement fragmented teaching in the process of college English teaching, do not pay attention to the coherence of knowledge. Also, students take one-sided learning without systemic understanding, and fail to think about relevant knowledge in practical application process timely, which causes greatly adverse influence on the learning effect. Thus, in order to effectively improve the overall quality of college English teaching and give play to the practical effect of the output-oriented teaching method, we should pay attention to the systematicness of knowledge and make reasonable plans in the process of applying the output-oriented teaching method so as to help students establish a complete knowledge system, sort out the ins and outs of knowledge, with curriculum object as the main line, find out the key connection points, and deeply apply the output-oriented teaching method deep into all teaching activities, obtain the systematicness and integrity of knowledge, and effectively improve teaching quality.

\subsection{Highlight during the application of output-oriented teaching method to highlight students' principal position}

Students should not be passive recipients of knowledge in the learning process, instead, they should constantly enrich and improve new knowledge, build a knowledge framework, and thus improve their overall quality based on their own knowledge system, which should be completed by students to take the initiative. However, under the traditional concept of education, students didn $\square \mathrm{t}$ maximize their initiative and their main position in the classroom has been completely replaced by the teacher's explanation so that they learn totally in line with the teacher's ideas without active thinking. Therefore, when teachers apply the output-oriented teaching method in college English teaching, they should pay great attention to the student's dominant position, actively innovate the teaching style, give full play to teachers $\square$ guiding role, enhance students $\square$ subjective initiative, and lead the students to think actively and initiatively, so as to change shortcomings of passively accepting knowledge in the past, gradually develop students $\square$ independent learning habits, strengthen their learning confidence, and lay a solid foundation for further study in the future.

\section{Summary}

To sum up, the output-oriented teaching method as an effective teaching method if applied in college English teaching will have a very positive effect on improving teaching quality. Thus, teachers should pay attention to the output-oriented teaching method, and innovate and improve the application strategy of the output-oriented teaching method in teaching practice, deepen the understanding of the output-oriented teaching method, and formulate scientific and reasonable teaching targets, maximally give play to the actual function of the output-oriented teaching method, timely solve problems in the application process, and promote the constant improvement of college English teaching quality. 


\section{References}

[1] Wen Qiufang. The Application of Output Drive Hypothesis in College English Teaching: Reflections and Suggestions, Foreign Language World, 2013(6)14-22.

[2] Wen Qiufang. Construction of “output-oriented method” theoretical system, Foreign Language Teaching and Research, 2015(4)547-640.

[3] Wen Qiufang. Chinese characteristics of “output-oriented method”, Modern Foreign Languages, 2017(3):348-438.

[4] Zhang Wenjuan, College English Teaching Practice Based on "Output-oriented Method", Foreign Language Teaching and Research, 2016(2):106-114.

[5] Zhang Lingli, Studies on Teaching Effectiveness of "Output-oriented Method", Modern Foreign Languages, 2017(3):369-376.

[6] Zhu Lili, Application of Output-oriented Teaching Method in College English Teaching, Campus English (midmonth), 2017(2):42-43.

[7] Cai Hongyan. Application of Output-oriented Teaching Method in College English Teaching, Journal of Heze University, 2016(6):111-114.

[8] Qi Can. Apply "Output Driven-Input-Initiated" Mode to Promote College English Teaching in Local Engineering Colleges, Campus English (Later-month), 2017(2):42-43.

[9] Chen Lvzhan. Exploration and Practice of College English Flipping Class Mode under the Guidance of Output-oriented Method.

[10] Li Donghui. Application of Output-oriented Method in College English Teaching in Art Colleges, Journal of Changchun Normal University (humanities and social sciences edition), 2018(2):192-194. 